\title{
RESEARCH
}

SCIEnTIA Marina 70S3

R. Sardá, G. San Martín, E. López, D. Martin

December 2006, 197-207, Barcelona (Spain)

and D. George (eds.)

ISSN: 0214-8358

\section{Seasonal dynamics of soft-bottom polychaetes in Izmir Bay (Aegean Sea, eastern Mediterranean)}

\author{
ZEKI ERGEN, MELIH ERTAN ÇINAR, ERTAN DAĞLI AND GÜLEY KURT
}

Ege University, Faculty of Fisheries, Department of Hydrobiology, 35100 Bornova, Izmir, Turkey.

E-mail: cinar@sufak.ege.edu.tr

\begin{abstract}
SUMMARY: Seasonal dynamics of soft-bottom polychaetes were investigated at 29 stations (depths: 8-77 m) in Izmir Bay (Aegean Sea, eastern Mediterranean) between 1997 and 2002. A total of 396 species belonging to 44 families were encountered, of which 32 species were new records for the Turkish fauna. Diversity and evenness index values were high at stations located in the outer part of the bay, whereas azoic conditions occurred in the polluted inner part of the bay, particularly in summer and autumn (fall). The highest population density was recorded at station 29 (inner part), with 11620 ind. $\mathrm{m}^{-2}$, where Capitella capitata capitata was the most dominant species $\left(6820\right.$ ind. $\left.\mathrm{m}^{-2}\right)$. Stations located in the semi-polluted zone of the bay were generally characterized by high biomass values (max. $33.6 \mathrm{~g} \mathrm{~m}^{-2}$ ). The cluster and nMDS analysis showed that the soft-bottom of the bay has four major polychaete communities, mainly structured by prevailing environmental conditions and types of substratum.
\end{abstract}

Keywords: polychaetes, seasonality, pollution, assemblages, exotic species, Aegean Sea, eastern Mediterranean.

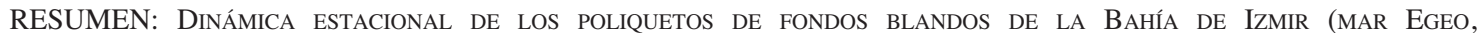
MEDITERRÁNEO ORIENTAL). - La dinámica estacional de los poliquetos que habitan los fondos blandos de la Bahía de Izmir (mar Egeo, Mediterráneo oriental) fue investigada en 29 estaciones durante el periodo comprendido entre 1997 y 2002 . Un total de 396 especies pertenecientes a 44 familias fueron encontradas. De las especies identificadas, un total de 32 constituyen nuevas citas para la fauna de Turkia. Los valores de diversidad y de "evenness" fueron altos en las estaciones localizadas en las zonas más externas de la bahía, mientras que las condiciones azoicas encontradas fueron los responsables de los valores obtenidos en la parte más interna y más contaminada, particularmente en verano y otoño. La más alta densidad poblacional fue hallada en la estación 29 con 11620 ind. $\mathrm{m}^{-2}$, en donde la especie Capitella capitata capitata fue la especie dominante $\left(6820\right.$ ind. $\left.\mathrm{m}^{-2}\right)$. Las estaciones localizadas en zonas semicontaminadas se caracterizaron por su alta biomasa (máximo de $33.6 \mathrm{~g} \mathrm{~m}^{-2}$. Los análisis estadísticos multivariantes realizados muestran que los fondos blandos de la Bahía de Izmir presentan 4 comunidades de poliquetos, preferentemente estructuradas en función de la contaminación ambiental y el tipo de sedimento.

Palabras clave: poliquetos, estacionalidad, contaminación, facies, especies exóticas, mar Egeo, Mediterráneo oriental.

\section{INTRODUCTION}

Polychaetes comprise the majority of faunal components of soft-bottom benthic communities (Knox, 1977) and can be used as "markers" of different ecological conditions (Gambi and Giangrande, 1986). Some polychaete species that are very tolerant of environmental variables have also successfully been utilized in pollution monitoring studies (Reish, 1955; Bellan et al., 1988). Increase in industrialisation, human population and marine transportation in Izmir Bay and its periphery since the 1970's has resulted in chronic pollution particularly in the inner part of the bay which has weak circulation. The main pollutants affecting the bay water quality are organic matter, suspended 
matter, hydrocarbons, metals and pathogenic organisms, all mainly derived from domestic and industrial wastes $(50 \%)$, rainfall $(15 \%)$, rivers and streams (10\%) and agricultural sources (10\%) (UNEP, 1994).

Due to eutrophication, the primary production (Chlorophyll-a) of the bay was estimated to be almost 6-8 times higher than the eastern Aegean production (Balci et al., 1995). The polluted zone of the bay has gradually extended from the inner region of the bay towards the relatively less disturbed middle and outer regions. Since the Gediz Plain is subjected to intensive farming and industrialization, the Gediz River, which enters the outer part of the Izmir Bay (Fig. 1), contributes considerably to the prevailing pollution in Izmir Bay (Ergen et al., 2002a). In early 2000, a wastewater treatment plant began to treat domestic and industrial wastes discharged into the bay. This plant treated the wastes at ca. $60 \%$ capacity between 2000 and 2001. A recent study showed that the capacity of the wastewater plant is sufficient for removal of nitrogen from the wastes, but inadequate for removal of phosphate (Kontas et al. 2004).

The present study was carried out before and after the installation of the waste water treatment plant, and aimed to determine the spatio-temporal distributions of soft-bottom polychaetes in Izmir Bay between 1997 and 2002.

\section{MATERIAL AND METHODS}

\section{The study area}

Izmir Bay is one of the largest embayments along the eastern coast of the Aegean Sea. From the standpoint of its topographical and hydrographical characteristics, Izmir Bay was divided into three sections: inner bay, middle bay and outer bay. The inner bay, which extends between the head of the Bay and the Yenikale lighthouses and has a depth ranging from $0-20 \mathrm{~m}$ (average $10 \mathrm{~m}$ ), is heavily polluted mainly by domestic and industrial activities. The middle and outer parts of the bay, with average depths of $16.3 \mathrm{~m}$ (range: $0-40 \mathrm{~m}$ ) and $29 \mathrm{~m}$ (range: 0-70 $\mathrm{m}$ ) respectively, receive less pollutants. In the outer bay, the Gediz River is the main source of pollution. Physico-chemical characteristics of the bay have been recently well documented: water and sediment quality by Kucuksezgin (1996), Aksu et al. (1998) and Atgin et al. (2000); hydrogen suphide and odour problem by Müezzinoğlu et al. (2000); physical features by Say1n (2003); nutrient and iron enrichment by Bizsel and Uslu (2000); eutrophication processes by Balci et al. (1995), Bizsel et al. (2001) and Kontaş et al. (2004).

According to Sayın (2003), Izmir Bay seawater is composed of five different water masses. These are the polluted inner Bay waters, the transient water

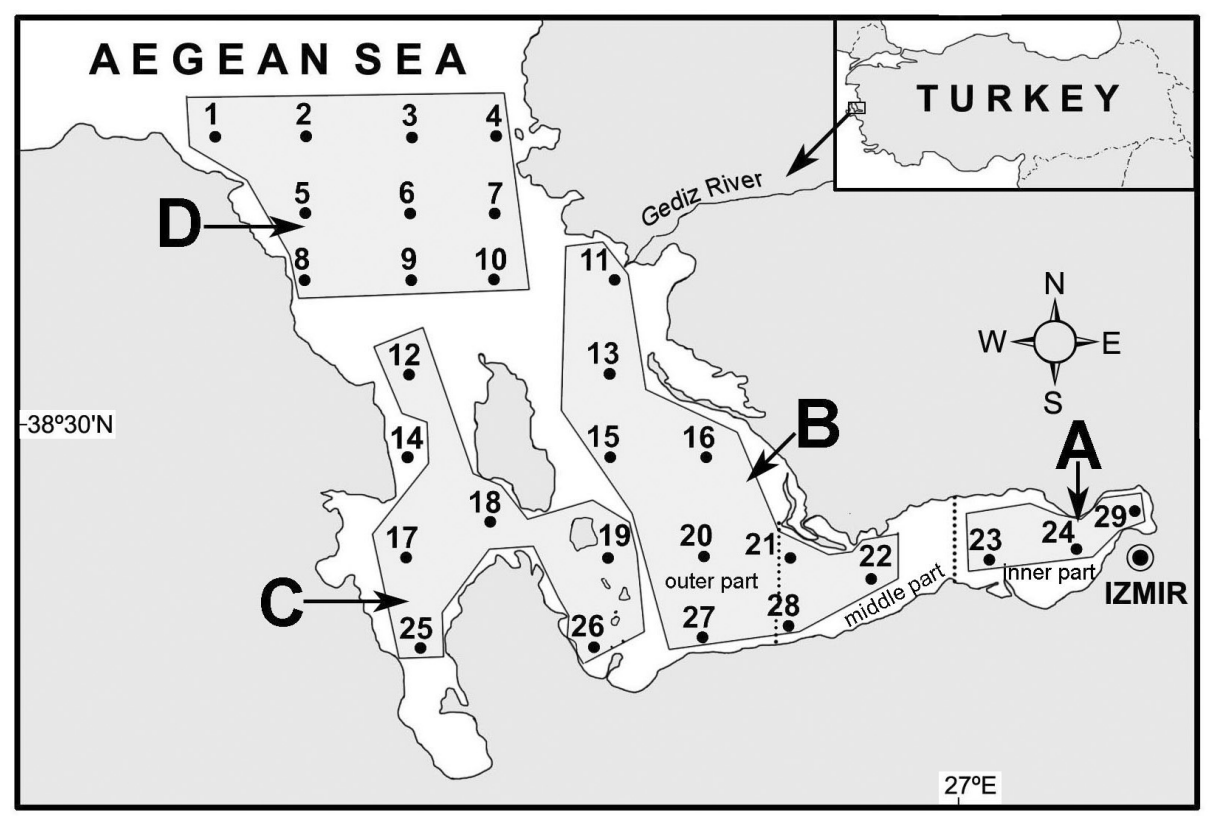

FIG. 1. - Map of the investigated area (Izmir Bay), with the locations of sampling sites. The station groupings (A-D) were made according to the cluster analysis presented in Figure 2. 
mass between clean waters and polluted waters, the clean water masses greatly influenced by a local upwelling near Gulbahce Bay, and the inflows of the Gediz River and Aegean Sea. Izmir Bay is under the influence of northerly winds throughout the year.

A recent seasonal study performed in Izmir Bay between 1996 and 2001 by Kontaş et al. (2004), who analysed water and sediment quality at stations where we collected the benthic material, showed that the temperature in the bay varied from ca. $10^{\circ} \mathrm{C}$ in December (average value: ca. $14^{\circ} \mathrm{C}$ ) to $28.6^{\circ} \mathrm{C}$ in August (average value: ca. $22^{\circ} \mathrm{C}$ ). The salinity varied from 21.4 (at a station near the Gediz River) to 39.9 psu (average value: ca. 39 psu); the density from 16.01 to $30.90 \mathrm{~kg} \mathrm{~m}^{-3}$ (average value: ca. $29 \mathrm{~kg}$ $\mathrm{m}^{-3}$ ). The Secchi disc depth, an indicator of relative primary production and pollution levels in the marine environment, had the maximum score $(29 \mathrm{~m})$ in the outer Bay in October and the minimum score $(0.3 \mathrm{~m})$ in the middle-inner parts of the bay in July.

Depths of the stations, where benthic material was collected for this study (Fig. 1), are as follows: $9 \mathrm{~m}$ (station 29); 10-20 m (stations 24, 23 and 14); 21-30 m (stations 16, 17, 22, 25, 26 and 28); 31-40 $\mathrm{m}$ (stations 11, 12, 13, 18 and 21); 41-50 m (stations 8, 15, 19 and 27); 51-60 $\mathrm{m}$ (stations 7, 4, 15 and 20); 61-70 m (stations 5, 6, 9 and 10); and 70-80 m (stations 1, 2 and 3). Biotopes of the stations can be classified as Posidonia oceanica (Linnaeus) Delile (station 14); fine sandy mud (stations deeper than 40 $\mathrm{m}$, and stations $11,13,22,23,24,29)$, sandy (station 16) and coarse sandy mud (stations shallower than $40 \mathrm{~m})$.

\section{Data collection and analysis}

Cruises of R/V K. Piri Reis to Izmir Bay, within the framework of the project "Izmir Bay Marine Research Project" supported by Izmir Metropolitan Municipality, collected seasonal soft-bottom samples using a Van Veen grab sampling an area of $0.1 \mathrm{~m}^{-2}$ at 29 stations between 1997 and 2002, except for winter in 1999 and 2000. Only one sample was taken from each station during the study period. On the board, soft-bottom samples were sieved through $0.5 \mathrm{~mm}$ mesh and the retained material was placed in separate jars containing $4 \%$ seawater formaldehyde solution. In the laboratory, samples were rinsed in fresh water and sorted according to taxonomic groups using a stereomicroscope, and preserved in $70 \%$ ethanol. Afterwards polychaetes were identi- fied and counted using both stereo- and compound microscopes. The wet weight of polychaetes was determined by a sensitive balance.

In order to interpret the quantitative data, Shannon-Weaver's diversity index (H') and Pielou's evenness index ( $\mathrm{J}$ ') were applied to the abundance of the species. The pooled abundance data of species, obtained per sampling station in each season, were analysed using cluster and non-metric multidimensional scaling (nMDS) techniques, based on the Bray-Curtis similarity, using the PRIMER package (see Clarke and Warwick, 2001). SIMPER analysis was performed in order to identify the percentage contribution of each species to the overall similarity within each group that was assessed according to results of the cluster analysis.

\section{RESULTS}

Faunistic analysis of polychaetes collected between 1997and 2002 at 29 stations in Izmir Bay yielded a total of 396 species belonging to 44 families, of which 32 species were new records for the Turkish fauna. New records are Malmgreniella polypapillata Barnich and Fiege, 2001; Harmothoe antilopes McIntosh, 1876; Gyptis propinqua Marion and Bobretzky, 1875; Podarkeopsis galangaui Laubier, 1961; Ancistrosyllis groenlandica McIntosh, 1879; Pilargis verrucosa Saint Joseph, 1899; Inermonephtys inermis (Ehlers, 1887); Lumbrineris nonatoi Ramos, 1976; Lumbrinerides amoureuxi Miura, 1980; Lumbrineriopsis paradoxa (Saint-Joseph, 1888); Ninoe armoricana Glemarec, 1968; Aricidea capensis bansei Laubier and Ramos, 1974; Aricidea catherinae Laubier, 1967; Aricidea fragilis mediterranea Laubier and Ramos, 1974; Aricidea simonae Laubier and Ramos, 1975; Aricidea suecica meridionalis Laubier and Ramos, 1974; Cirrophorus furcatus (Hartman, 1957); Paradoneis armata Glemarec, 1966; Spiophanes kroyeri reyssi Laubier, 1964; Magelona filiformis Wilson, 1959; Leiocapitella glabra Hartman, 1947; Poecilochaetus fauchaldi Pilato and Cantone, 1976; Monticellina dorsobranchialis (Kirkegaard, 1959); Ophelina acuminata Oersted, 1843; Ophelina cylindricaudata (Hansen, 1878); Clymenura tricirrata (Bellan and Reys, 1967); Lygdamis muratus (Allen, 1904); Sabellides octocirrata (Sars, 1835); Octobranchus lingulatus (Grube, 1863); Chone arenicola Langerhans, 1880; Chone longiseta 
$200 \bullet$ Z. ERGEN et al.
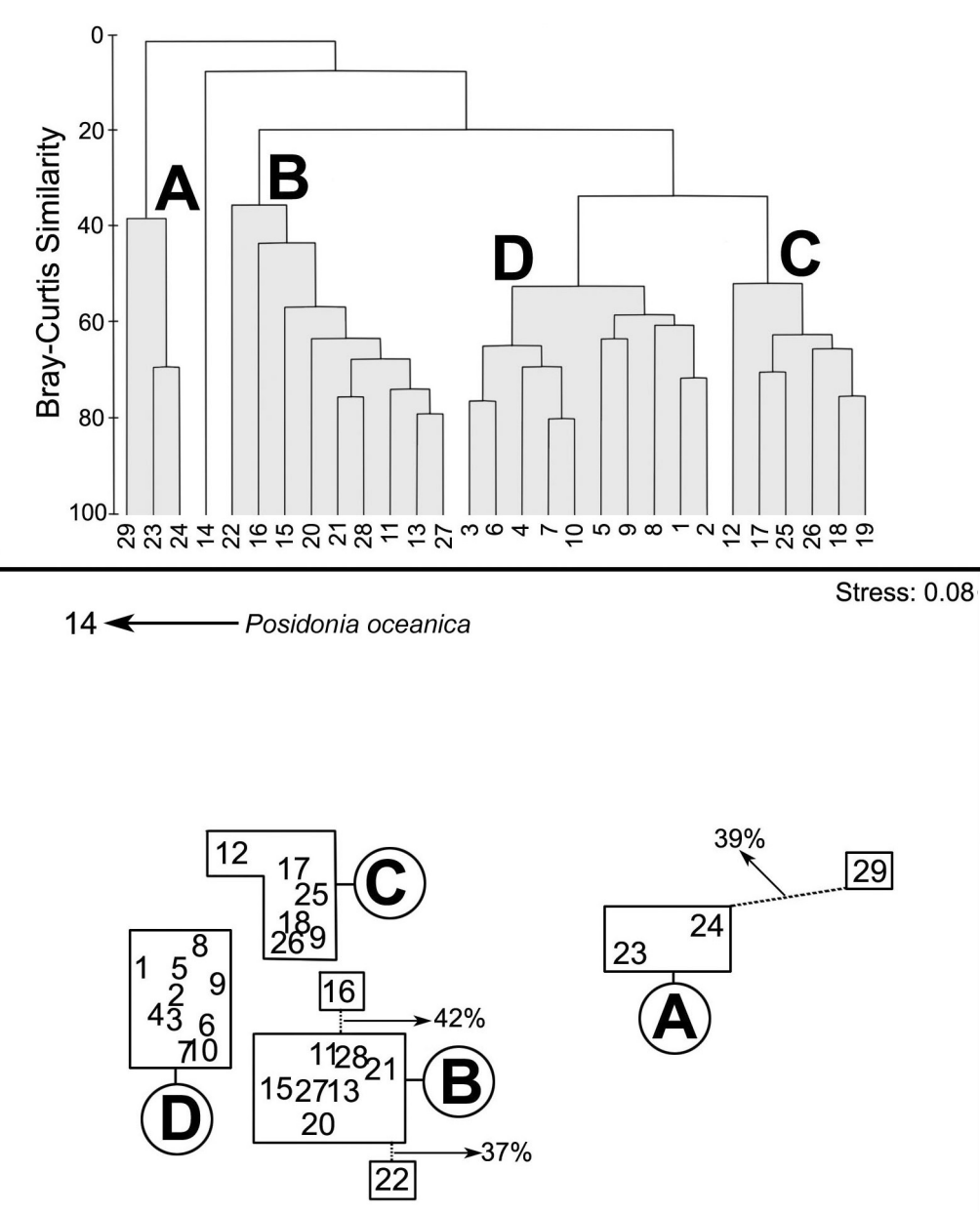

FIG. 2. - Groups (A-D) derived from the Bray-Curtis similarity analysis. nMDS plot showing similarity grouping of stations.

Malmgren, 1867 and Euchone southerni Banse, 1972. In addition, two species, Eunereis longissima (Johnston, 1840) and Ancistrosyllis hamata (Hartman, 1960), are new to the eastern coast of the Aegean Sea.

Of the 44 families, Syllidae and Sabellidae had the highest number of species, accounting for $13.7 \%$ and $6 \%$ of the total number of species, respectively. The families represented by only one species in the area are Amphinomidae (Chloeia venusta Quatrefages, 1865), Euphrosinidae (Euphrosine foliosa Audouin and Milne Edwards, 1833), Lacydonidae (Paralacydonia paradoxa), Cossuridae (Cossura soyeri), Sternaspidae (Sternaspis scutata) and Acrocirridae [Macrochaeta clavicornis (Sars, 1835)].

The results of nMDS and cluster analysis based on the pooled abundance data of the species collected between 1997 and 2002 are illustrated in Figure 2. According to these analyses, there are four distinct species associations (A-D) in the area, each having an average similarity higher than $50 \%$ (Table 1).
However, group A has two stations (23 and 24) connected to each other at high similarity $(65 \%)$ and one station (29) linked to these stations with relatively low similarity (39\%), all being located in the polluted inner part of Izmir Bay. Although all these stations were dominated by opportunistic polychaete species such as Ophiodromus pallidus (max density: 720 ind. $\mathrm{m}^{-2}$ at station 24 in April 2000), Neanthes succinea (Frey and Leuckart, 1847) (max. 40 ind. $\mathrm{m}^{-2}$ at station 23 in September 1998), Schistomeringos rudolphi (Delle Chiaje, 1828) (max. 190 ind. $\mathrm{m}^{-2}$ at station 29 in February 2002), Malacoceros fuliginosus (max. 330 ind. $\mathrm{m}^{-2}$ at station 29 in December 2001), Prionospio fallax (max. 560 ind $\mathrm{m}^{-2}$ at station 23 in January 1998), Polydora cornuta (1940 ind. $\mathrm{m}^{-2}$ at station 29 in February 2002) and Capitella capitata capitata (6820 ind. $\mathrm{m}^{-2}$ at station 29 in February 2002). station 29 had relatively high population densities of C. capitata capitata, S. rudolphii, M. fuliginosus, Polydora cornuta and Lanice conchilega (Pallas, 1766) (max. 240 ind. $\mathrm{m}^{-2}$ in April 1997), but 
TABLE 1. - Species contributing to similarity and dissimilarity within each groups (as shown in Figure 2), with their average similarity.

\begin{tabular}{|c|c|c|c|c|c|c|c|c|c|c|}
\hline & & & & & & & Dissi & ilarity & & \\
\hline & A & $\mathrm{B}$ & $\mathrm{C}$ & $\mathrm{D}$ & A-B & $\mathrm{A}-\mathrm{C}$ & A-D & $\mathrm{B}-\mathrm{C}$ & B-D & C-D \\
\hline Average Similarity/Dissimilarity & 53 & 60 & 63 & 63 & 85 & 88 & 92 & 60 & 60 & 57 \\
\hline Paralacydonia paradoxa (Fauvel, 1913) & - & - & - & 6 & - & - & - & - & 3 & 2 \\
\hline Ophiodromus pallidus (Claparède, 1864) & 7 & - & - & - & 4 & - & 3 & - & 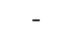 & 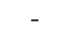 \\
\hline Sigambra tentaculata (Treadwell, 1914) & 5 & 7 & 7 & - & - & - & 3 & - & 5 & 5 \\
\hline Eunice vittata (Delle Chiaje, 1829) & - & - & 4 & - & - & 2 & - & 3 & - & 3 \\
\hline Lumbrineris gracilis (Ehlers, 1868) & - & 5 & 13 & 6 & - & 6 & 2 & 6 & - & 7 \\
\hline Lumbrineris latreillii (A.and M. Edwards, 1834) & - & 4 & 7 & 4 & - & 3 & - & 2 & - & 4 \\
\hline Aponuphis brementi Fauvel, 1916 & - & - & - & 3 & - & - & - & 2 & 2 & 2 \\
\hline Aricidea claudiae Laubier, 1967 & - & 10 & 18 & 8 & 4 & 8 & 2 & 7 & 4 & 12 \\
\hline Cirrophorus branchiatus Ehlers, 1908 & - & - & 4 & - & - & - & - & 2 & - & 3 \\
\hline Levinsenia gracilis (Tauber, 1879) & - & 4 & 5 & 7 & - & 2 & 2 & - & - & 2 \\
\hline Paradoneis lyra (Southern, 1914) & - & - & 3 & 3 & - & - & - & - & - & - \\
\hline Malacoceros fuliginosus (Claparède, 1868) & 3 & - & - & - & - & 3 & - & - & - & - \\
\hline Polydora cornuta Bosc, 1802 & 31 & - & - & - & 16 & 13 & 18 & - & - & - \\
\hline Prionospio fallax Soderstrom, 1920 & 18 & 4 & - & - & 5 & 5 & 8 & - & 3 & - \\
\hline Streblospio gynobranchiata Rice and Levin, 1998 & 20 & - & - & - & 8 & 7 & 9 & - & - & - \\
\hline Chaetozone spp. & - & 7 & - & 2 & 5 & - & - & 6 & 8 & - \\
\hline Cirriformia cf. tentaculata (Montagu, 1808) & - & 4 & - & - & 2 & - & - & 2 & 3 & - \\
\hline Monticellina heterochaeta Laubier, 1961 & - & 17 & 5 & 8 & 7 & - & 3 & 6 & 8 & - \\
\hline Capitella capitata capitata (Fabricius, 1780 ) & 8 & - & - & - & 15 & 13 & 16 & - & - & - \\
\hline Cossura soyeri Laubier, 1963 & - & - & - & - & - & - & - & - & 2 & - \\
\hline Magelona minuta Eliason, 1962 & - & - & - & 3 & - & - & - & - & - & - \\
\hline Sternaspis scutata (Ranzani, 1817) & - & 15 & - & - & 7 & - & - & 9 & 11 & - \\
\hline Melinna palmata Grube, 1870 & - & - & 2 & - & - & - & - & - & 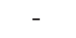 & 3 \\
\hline
\end{tabular}

less population density of Sigambra tentaculata and no specimens of Lumbrineris spp., Cossura soyeri and Chaetozone spp., which were dominant components of the polychaete assemblage at stations 23 and 24. Streblospio gynobranchiata, which appeared in abundance on the polluted bottom of the inner part of the bay in 2002, is one of the seven species contributing greatly to the similarity score calculated among the stations 23, 24 and 29 (Table 1). A high dissimilarity (ca.100\%) was estimated between group A and the other groups, with Polydora cornuta, C. capitata capitata and Streblospio gynobranchiata being mainly responsible for this distinct separation (Table 1).

Group B (including the stations 11, 13, 15, 16, $20,21,22,27$ and 28) is characterized by a relatively high number of species and high population densities of species such as Chaetozone spp. (1390 ind.m ${ }^{-2}$ at station 22 in December 2001), Monticellina heterochaeta (max. 540 ind. $\mathrm{m}^{-2}$ at station 28 in January 2001), Sternaspis scutata (max. 510 ind. $\mathrm{m}^{-2}$ at station 22 in August 2001) and Aricidea claudiae (max. 550 ind. $\mathrm{m}^{-2}$ at station 16 in July 2000). A high number of juvenile specimens of Cirriformia cf. tentaculata (2000 ind. $\mathrm{m}^{-2}$ ) and Sabellaria spinulosa Leuckart, 1849 (350 ind. $\mathrm{m}^{-2}$ ) were encountered at station 22 in July 1997 and April 1998, respectively. In contrast to the other stations within group B, the muddy bottom of station
22 was dominated by Chaetozone spp. and Sternaspis scutata, which resulted in a relatively low similarity (37\%) between this station and the others. The other station that linked to the stations within group B with a relatively low similarity value $(42 \%)$ is station 16 , which has relatively dense populations of the following species that are represented by a few individuals at the other stations: Micronephtys maryae San Martìn, 1982, Nepthys incisa Malmgren, 1865, Eunice vittata, Scoloplos armiger (O.F. Müller, 1776), Spio decoratus Bobretzky, 1870, Aricidea fragilis mediterranea, Magelona minuta and Heteromastus filiformis (Claparède, 1864).

Stations 12, 17, 18, 19, 25 and 26 constituted group $\mathrm{C}$, with an average similarity value of $63 \%$. This group differed from the others in having relatively dense populations of Pilargis verrucosa, Sigambra tentaculata, Syllis garciai (Campoy, 1982), Eunice vittata, Lumbrineris gracilis, L. latreilli, Scoletoma impatiens (Claparède, 1868), Aricidea claudiae, Cirrophorus branchiatus, Paradoneis lyra, Levinsenia gracilis, Euclymene oerstedi (Claparède, 1863), Melinna palmata, Chone collaris Langerhans, 1880 and C. filicaudata Southern, 1914.

The last group, D, which includes the deeper stations (stations 1-10), had a set of abundant species either not numerically important or absent in the 


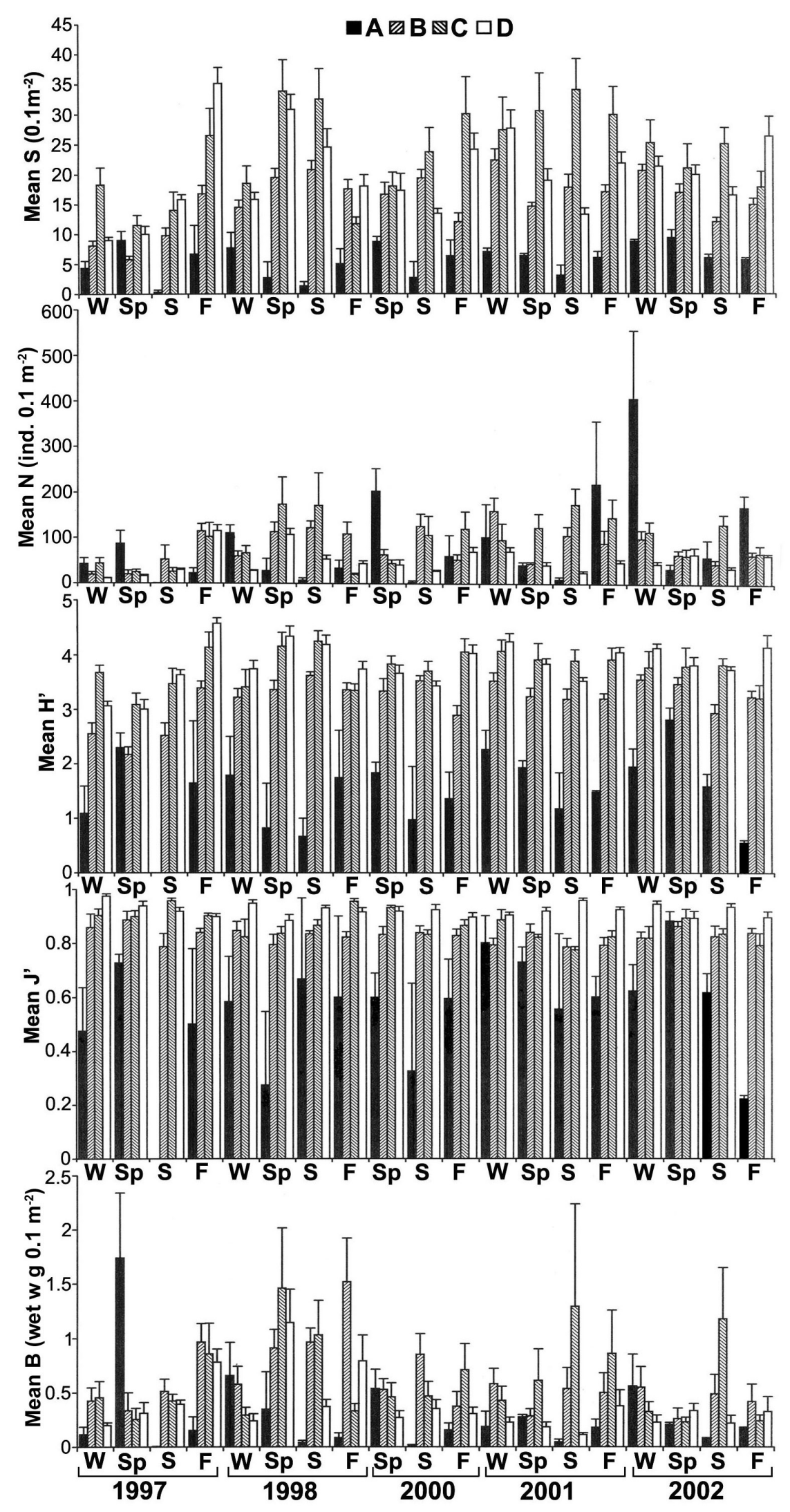

FIG. 3. - Seasonal fluctuations of mean number of species $(\mathrm{S})$, number of individuals $(\mathrm{N})$, and diversity index $\left(\mathrm{H}^{\prime}\right)$, evenness index $\left(\mathrm{J}^{\prime}\right)$ and biomass (B) values at each group (A-D) during 1997-2002, with + standard error. W, winter; Sp, spring; S, summer; F, fall. 
other groups: Arichlidon reyssi (Katzmann, Laubier and Ramos, 1974), Paralacydonia paradoxa, Eurysyllis tuberculata Ehlers, 1864, Aponuphis brementi, Ninoe armoricana, Paraprionospio pinnata (Ehlers, 1901), Prionospio dubia Day, 1961, Ampharete acutifrons (Grube, 1860), Amphicteis gunneri (Sars, 1835), Terebellides cf. stroemi (Sars, 1835) and Ditrupa arietina (O. F. Müller, 1776). This group included relatively low population densities of key species such as Lumbrineris gracilis, $L$. latreillii, Aricidea claudiae, Chaetozone spp. and Monticellina heterochaeta. Within group D, two subgroups are discernible, both having a somewhat similar species composition and abundance, but the subgroup including stations 3, 4, 6, 7 and 10 possesses a relatively high number of specimens of $A$. acutifrons, A. claudiae and Cossura soyeri, but few individuals of Chone collaris.

Station 14 characterised by a Posidonia oceanica meadow had a diverse polychaete assemblage in all seasons and showed little faunal affinity with the other stations.

Figure 3 indicates the mean numbers of species, individuals, diversity index, evenness index and biomass values estimated seasonally in each group from 1997-2002. Only the diversity of species present varied significantly in relation to seasons (1- way ANOVA, $\mathrm{p}<0.05)$. No significant difference was found in the number of individuals, diversity, evenness and biomass $(p>0.05)$ between the seasons.

The lowest mean number of species was always found in group A (except in spring 1997) and the highest mean number of species generally in group C. Stations located in the polluted inner bay were represented by a very low number of species in summer and a relatively high number of species in winter and spring. Azoic conditions were recorded at station 29 in summer and sometimes in autumn from 1997-2001. However, such conditions did not occur in 2002, even in summer, and station 29 possessed at least 5 species (maximum 8) in all seasons of 2002.

Mean polychaete density varied among seasons and associations, but attained its highest scores in group A in spring, autumn and winter. As Capitella capitata capitata (6820 ind. $\mathrm{m}^{-2}$ ) and Polydora cornuta (1940 ind. $\mathrm{m}^{-2}$ ) exceptionally dominated station 29 in winter 2002, the mean density score had a peak in this period, with a high standard error value due to high polychaete density (9830 ind $\mathrm{m}^{-2}$ ) at station 29 but relatively low densities at stations 23 and 24 (ca. 1600 ind. $\mathrm{m}^{-2}$ ). Group D is characterized by rel- atively low polychaete densities [range: 60 (at station 3 in winter 1997) - 2020 (at station 9 in autumn 1997 ) ind. $\mathrm{m}^{-2}$. The mean polychaete densities of groups B and C ranged from 190 (winter 1997) to 1600 (winter 2001) ind. $\mathrm{m}^{-2}$, and from 200 (autumn 1998 ) to 1740 (summer 2001) ind. $\mathrm{m}^{-2}$, respectively.

The mean diversity value was always low in group A, being lower than 2 in all sampling periods, except in spring 1997, winter 2001 and spring 2002 (Fig. 3). As for the evenness index values, group A generally showed the lowest scores, except in winter 2001 and spring 2002. The highest mean diversity index values were found in groups $\mathrm{C}$ and $\mathrm{D}$, ranging from 3.08 (spring 1997) to 4.25 (summer 1998), and from 3 (spring 1997) to 4.57 (autumn 1997), respectively.

The biomass of polychaetes attained its maximum level $\left(50 \mathrm{~g} \mathrm{~m}^{-2}\right)$ in summer 2001 at station 25, where a large individual of Marphysa sanguinea (Montagu, 1815) (3.52 g) occurred. Similarly, large specimens of Lanice conchilega solely found in spring 1997 at station 29 increased the mean biomass estimated in group A for this period. The mean polychaete biomass ranged from 0.03 (summer 1997 ) to $17.4 \mathrm{~g} \mathrm{~m}^{-2}$ (spring 1997) in group A; from 2.6 (spring 2002) to $15.2 \mathrm{~g} \mathrm{~m}^{-2}$ (autumn 1998) in group B; from 2.3 (spring 2002) to $14.6 \mathrm{~g} \mathrm{~m}^{-2}$ (spring 1998) in group $C$; and from 1.13 (summer 2001) to $11.4 \mathrm{~g} \mathrm{~m}^{-2}$ (spring 1998) in group D.

The mean scores of the community parameters estimated in samples collected from station 14 are $30.2 \pm 2.8$ (range: 14 in winter 1998; 58 in winter 2001) for the number of species; $112 \pm 22.5$ ind 0.1 $\mathrm{m}^{-2}$ (range: 180 in winter 1998; 4290 ind. $\mathrm{m}^{-2}$ in autumn 2001) for the number of individuals; $4.21 \pm 0.09$ (range: 3.48 in summer 2002; 4.83 in autumn 1998) for diversity index; $0.88 \pm 0.01$ (range: 0.80 in spring 2000; 0.98 in winter 1997) for evenness index; and $0.95 \pm 0.13 \mathrm{~g} 0.1 \mathrm{~m}^{-2}$ (range: 2 in winter 1997; $21.4 \mathrm{~g} \mathrm{~m}^{-2}$ in winter 1998) for biomass.

According to pooled data derived from the seasonal samples between 1997 and 2002, group A was represented by a total of 59 polychaete species and 4907 individuals; group B by 190 species and 13457 individuals; group C by 256 species and 10574 individuals; and group D by 281 species and 9102 individuals. The dominant species of each group varied according to seasons, but when all data are taken into account, the dominant components of group A were Capitella capitata capitata (30\% of the total population), Polydora cornuta (26\%), Streblospio gyno- 
branchiata (12\%), Prionospio fallax (10\%) and Ophiodromus pallidus (5\%), respectively. However, at station 29 , where only 29 polychaete species were found during the course of the study, the dominance levels of the opportunistic species were very high: $C$. capitata capitata (50\%), P. cornuta (23\%) and Streblospio gynobranchiata (8\%). Group B was dominated by Sternaspis scutata (13\%), Monticellina heterochaeta (12\%) and Chaetozone spp. (10\%); group C by Aricidea claudiae (13\%), Lumbrineris gracilis (9\%) and Sigambra tentaculata (5\%); group D by $M$. heterochaeta (7\%), L. gracilis $(6 \%)$ and Levinsenia gracilis (5\%). Station 14 had 172 species and 2151 specimens, and was characterized by high abundance of the species Platynereis dumerilii (Audouin and Milne Edwards, 1833) (9\%), Eunice vitatta (8\%) and Syllis garciai $(8 \%)$.

\section{DISCUSSION}

Faunistic analysis of soft-bottom polychaetes inhabiting Izmir Bay showed that the area is biodiverse, harbouring a total of 396 species, of which 32 are new records for the coasts of Turkey. The previous studies carried out in the bay also pointed out its high biological diversity (Geldiay and Kocataş, 1972; Ergen, 1976; Kocataş, 1978; Çinar et al. 1998). However, domestic and industrial pollution, which was first detected in the bay in the beginning of the1970's, resulted in a decrease in the living components of the ecosystem of the inner part of the bay and favoured dense settlement of opportunistic polychaete species in the area (Geldiay and Ergen, 1972; Ergen, 1979; Geldiay et al. 1979; Kocataş et al., 1986; Koçak et al., 1999).

Eutrophication is frequently reported particularly from the inner part of the Bay (Balci et al., 1995). The concentration of total inorganic nitrogen was 3.8 and $668 \mu \mathrm{M}$ in the outer and inner parts of the bay, respectively (Kucuksezgin, 1996). The bay is also very productive; the average primary production values were calculated as 264, 463 and $726 \mathrm{mg}$ $\mathrm{C} / \mathrm{m}^{2} /$ day in the western, central and eastern parts of the bay respectively (Balci et al., 1995). Azoic conditions and odorous biogenic sulphurous gases were reported to be serious problems in the area (Kocataş, 1980; Müezzinoğlu et al., 2000; Doğan et al., 2005). Kocataş et al. (1987) carried out a long-term monitoring study in the inner part of the bay between 1974 and 1983, and did not find azoic conditions even at the station located in the innermost part of the bay. They reported that the station had an average of 16 benthic species in 1974, whereas it possessed only 3 species in 1983. After the mid 1980's $\mathrm{H}_{2} \mathrm{~S}$ odour problems, created by organic pollution and anoxia in the shallowest and most stagnant part of Izmir Bay continuously fed by polluted inputs of the rivers, were evident, especially during the long warm and dry season. However, an improvement in the environmental quality of the bay was expected after a new waste water treatment plant came into operation in early 2000. The present study includes periods before and after the establishment of the treatment plant and may indicate the efficiency of the plant in controlling and reducing industrial and domestic wastes pouring into the bay. As can be seen from Figure 4, azoic conditions at station 29, which is located in the innermost part of the bay, were found in every summer (except for 2002), in autumn 1997 and 1998 and in spring 1998. However, benthic samples taken during 2002 at this station had at least 5 species (autumn). The most interesting finding is that the sample taken in July 2002 at station 29 contained six species: Sigambra tentaculata (20 ind. $\mathrm{m}^{-2}$ ), Glycera unicornis Savigny, 1818 (40 ind. $\mathrm{m}^{-2}$ ), Polydora cornuta (30 ind. $\mathrm{m}^{-2}$ ), Prionospio fallax (230 ind. $\left.\mathrm{m}^{-2}\right)$, Streblospio gynobranchiata $(990$ ind. $\mathrm{m}^{-2}$ ), and Capitella capitata capitata (30 ind. $\mathrm{m}^{-}$ $\left.{ }^{2}\right)$ This suggests that the plant is effective in reducing pollution and has made the area more favourable even in summer for the settlement of polychaetes. Polychaetes are known to be colonisers of bottoms where a pollution abatement programme had been established (Pearson and Rosenberg, 1978). However, Kontas et al. (2004) found no significant differences in the overall average values of nutrient concentrations between the samples before and after the plant became operational.

The species composition of polychaetes encountered in the bay during the study is somewhat similar to those previously reported from the soft-bottom communities of the Mediterranean Sea. The most striking difference is that the present study reports the settlement of non-indigenous species such as Leonnates persicus (Wesenberg-Lund, 1949), Polydora cornuta and Streblospio gynobranchiata. The former is a Lessepsian migrant and has become established in Izmir Bay (Çinar et al., 2002). A recent study showed that the population density of this species inhabiting soft substratum of the northern part of the Levant Sea is positively correlated 

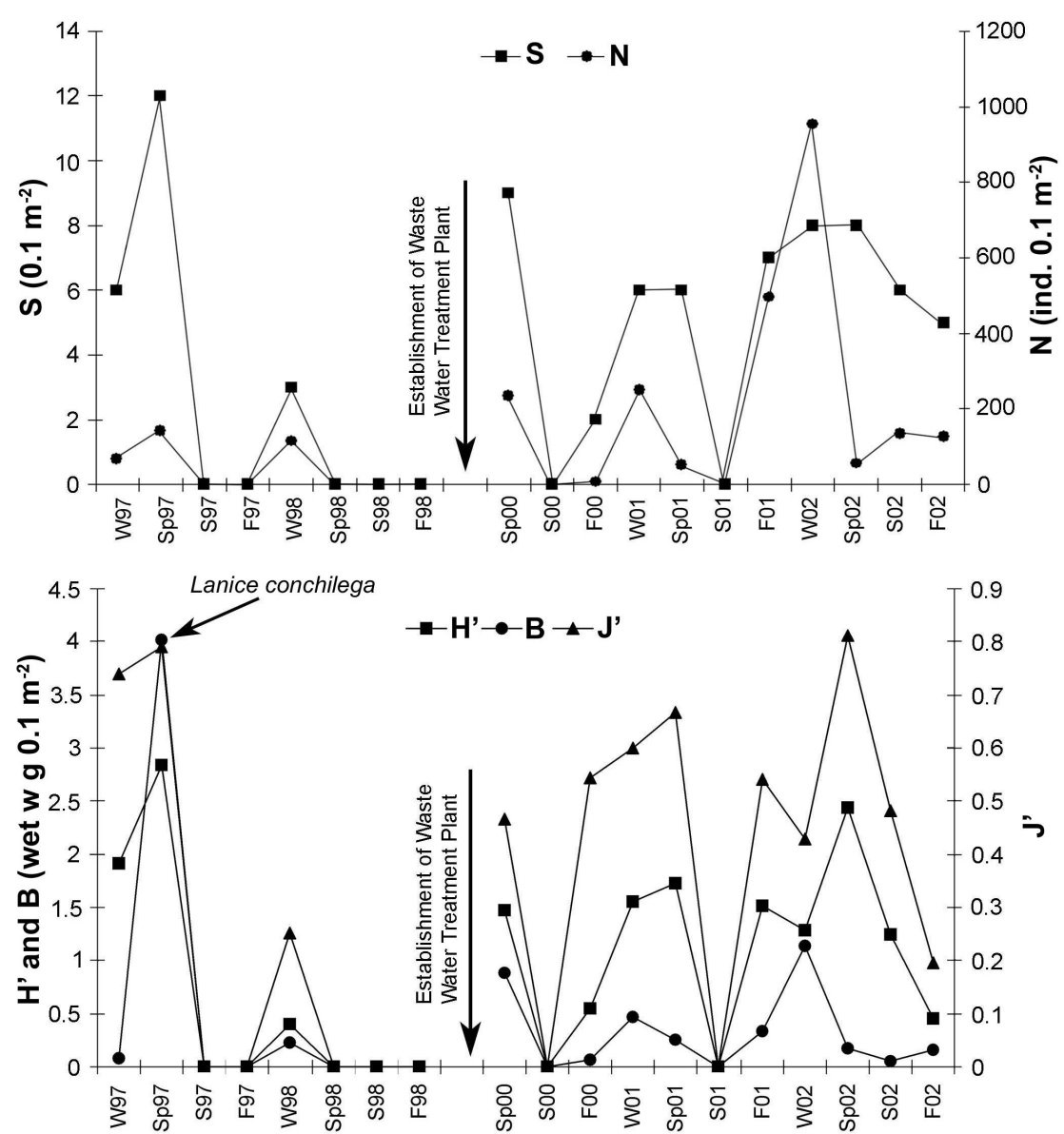

Fig. 4. - Seasonal fluctuations of number of species (S), number of individuals $(\mathrm{N})$, diversity index $\left(\mathrm{H}^{\prime}\right)$, evenness index $\left(\mathrm{J}^{\prime}\right)$ and biomass $(\mathrm{B})$ values at station 29 before and after waste water treatment plant became operative in early 2000 . W, winter; Sp, spring; S, summer: F, autumn (fall).

with total carbonate and total inorganic carbon contents of the sediment (Ergev et al., 2003). Similarly, it was found at stations 11, 13, 27 and 28 in Izmir Bay, which receive high loads of organic material from the inner part of the bay and the Gediz River. This species formed a dense population (100 ind.m$\left.{ }^{2}\right)$ at station 13 in autumn 2002. The occurrence and impacts of the exotic spionid species, Streblospio gynobranchiata and Polydora cornuta, on the native fauna were documented in the inner part of Izmir Bay by Çinar et al. (2005). The other Lessepsian species found in the area are Lysidice collaris Grube, 1870, Metasychis gotoi (Izuka, 1902), Rhodine loveni Malmgren, 1865, Monticellina dorsobranchialis and Pista unibranchiata Day, 1963. However, their status of Lessepsian migrants should be re-analysed (Ergen et al., 2002b).

The results of multivariate analysis showed that there are four major species assemblages in the soft bottom of Izmir Bay (Fig. 2): the group developed in the polluted inner bay and characterized by relatively high population densities of opportunistic species such as Capitella capitata capitata, Malacoceros fuliginosus, Polydora cornuta and Ophiodromus pallidus; group B comprising stations not far from the sources of pollution discharges and under effects of inflows of the Gediz River; group C comprising shallow water stations, not strongly influenced by pollution and having coarse sandy mud; the last group $\mathrm{D}$ being located at the opening of the Bay, including deeper stations and having fine sandy mud. However, stations 16 and 22 within group B are linked to the other stations by relatively low similarity values. Station 16 has a sandy bottom, where Nephtys incisa, N. hombergi Savigny, 1818, Scoloplos armiger, Spio decoratus and Owenia fusiformis Chiaje, 1842, (typical species of sandy sediments and that can tolerate small amounts of mud and organic matter in the substrate (Gambi and Giangrande, 1986)), are represented by a relatively high number of individuals. The area around station 22 can be accepted as the transitional or semi-polluted zone as it comprised faunal elements from both adjacent communities. A total of 85 species 
were found in this station and the diversity index values ranged from 1.78 (summer 2002) to 3.59 (autumn 1997), with a mean value of $2.85 \pm 0.12$ $\mathrm{SE}$. The relatively high number of species and diversity index values at this intermediate zone station can be explained as an "intensity effect": caused by the spatial complexity (mixed) of the sediment that results in a large number of niche spaces (Gambi and Giangrande, 1986) and the "edge effect" due to overlapping of adjacent communities (Dajoz, 1977). Station 14 within a Posidonia oceanica meadow had a specific polychaete assemblage characterized by high diversity and evenness, showing little affinity with unvegetated bottoms. Posidonia oceanica, a species endemic to the Mediterranean Sea, is known to host diversified polychaete assemblages both in its western (Gambi et al., 1995) and eastern (Çinar, 2003) regions due to its long, broad leaves and scaled rhizomes penetrating well into the sediment that provide a number of microhabitats and niches for both epifauna and endofauna.

According to statistical and faunisticanalyses, pollution, sediment structures and water depth seem to be the main factors governing the distribution of polychaetes in Izmir Bay. It is well known that depth, seasonality and particle size of sediment are the most important factors controlling distribution of polychaetes (Tom and Galil, 1991; Mackie et al., 1997; San Martín et al., 2000). Gambi and Giangrande (1986) and Mackie et al. (1997) found that depth affects both density and diversity of benthic communities, as the finer sediment increases with depth. The same result was also found in the present study where deeper stations located in the outer part of the bay had generally high diversity index values, with no conspicuous dominant species.

Sardá et al. (1999) determined clear seasonal trends in the abundance and biomass of macroinfaunal assemblages at sublittoral stations of the Bay of Blanes, with peaks during spring, followed by a striking decline throughout summer and lower values during autumn and winter. The authors concluded that seasonal patterns of reproductive events are the main factors which explain such markedly repeated cycles. The seasonal dynamics of macroinfauna species was reported to be also influenced by the availability of food and the presence of predators (Sardá et al., 1995). However, Oug (2000) examined soft-bottom macrofauna from the fjords of northern Norway from 1979-1982 and reported that species number and densities varied irregularly with peak values occurring at different times of the year. He concluded that the lack of seasonality is mainly due to the stable physical conditions and the irregular nutrient input in the fjord basin. Apart from number of species that showed a significant difference between seasons, the seasonal fluctuations in number of individuals, and values of diversity, evenness and biomass are not statistically significant in this study. The same result was also found by Çinar et al. (1998), who investigated seasonal trends of faunal components associated with a Zostera marina bed in the Aegean Sea.

It can be concluded that pollution in the inner part of the Bay has been gradually diminishing since the waste water treatment plant became operational. Azoic conditions, which always occurred in summer in the inner part of the bay between 1997 and 2001, did not reoccur in 2002, suggesting that the area is in the process of recovery. Future monitoring studies to be undertaken in Izmir Bay will undoubtedly provide further information on the efficiency of the plant in reducing pollution in the area.

\section{ACKNOWLEDGEMENTS}

We are much indebted to our colleagues in the Department of Hydrobiology, Ege University for their help in collecting and sorting the benthic material, and to the crews and scientific personnel of the $\mathrm{R} / \mathrm{V}$ K. Piri Reis for their help in obtaining benthic samples.

\section{REFERENCES}

Aksu, A.E., D. Yaşar and O. Uslu. - 1998. Assessment of marine pollution in Izmir Bay: Heavy metal and organic compound concentrations in surficial sediments. Turk. J. Engin. Environ. Sci., 22: 387-415.

Atgin, R.S., O. El-Agha, A. Zararsiz, A. Kocataş, H. Parlak and G. Tuncel. - 2000. Investigation of the sediment pollution in Izmir Bay. Spectrochimica Acta, part B, 55: 1151-1164.

Balci, A., F. Kucuksezgin, A. Kontas and O. Altay. - 1995. Eutrophication in Izmir Bay, Aegean Sea. Toxicol. Environ. Chem., 48: 21-48.

Bellan, G., G. Desrosiers and A. Willsie. - 1988. Use of an annelid pollution index for monitoring a moderately polluted littoral zone. Mar. Pollut. Bull., 19: 662-665.

Bizsel, N. and O. Uslu. - 2000. Phosphate, nitrogen and iron enrichment in the polluted Izmir Bay, Aegean Sea. Mar. Environ. Res., 49: 101-122.

Bizsel, N., H.A. Benli, C.K. Bizsel and G. Metin.-2001. A synoptic study on the phosphate and phytoplankton relationship in the hypereutrophicated Izmir Bay (Aegean Sea). Turk. J. Engin. Environ. Sci., 25: 89-99.

Çinar, M.E. - 2003. Ecological features of Syllidae (Polychaeta) 
from shallow-water benthic environments of the Aegean Sea, eastern Mediterranean. J. Mar. Biol. Ass. U.K., 83: 737-745.

Çinar, M.E., Z. Ergen and E. Dağll. - 2002. Occurrence of the lessepsian species Leonnates persicus (Polychaeta: Nereididae) in Izmir Bay, Aegean Sea. J. Mar. Biol. Ass. U.K., 82: 811-815.

Çinar, M.E., Z. Ergen, B. Öztürk and F. Kırkım. - 1998. Seasonal analysis of zoobenthos associated with a Zostera marina L., bed in Gulbahce Bay (Aegean Sea, Turkey). P.S.Z.N.: Mar. Ecol., 19: 147-162.

Çinar, M.E., Z. Ergen, E. Dağlı and M.E. Petersen. - 2005. Alien species of spionid polychaetes (Streblospio gynobranchiata and Polydora cornuta) in Izmir Bay, eastern Mediterranean. J. Mar. Biol. Ass. U.K., 85: 821-827.

Clarke, K.R. and R.M. Warwick. - 2001. Change in marine communities: an approach to statistical analysis and interpretation, $2^{\text {nd }}$ edition. PRIMER-E: Plymouth.

Dajoz, R. - 1977. Manuale di Ecologia, third edition. ISEDI.

Doğan, A., M.E. Cinar, M. Önen, Z. Ergen and T. Katağan. - 2005. Seasonal analysis of soft-bottom zoobenthic communities in polluted and unpolluted areas of Izmir Bay (Aegean Sea). Senckenberg. mar., 35: 133-145.

Ergen, Z. - 1976. Izmir Körfezi ve Civarı Poliketlerinin Ekolojik ve Taksonomik Özellikleri. Ege Üniv. Fen Fak. Ilmi Rap. Ser., 1-73.

Ergen, Z. - 1979. Izmir Körfezi’nin Pollusyonunun Poliket (Polychaeta-Annelida) Populasyonunun Dağılımı Üzerine Etkileri. T.U.J.J.B. Yayinlari, 11: 77-82

Ergen, Z., C. Dora and M.E. Çinar. - 2002a. Seasonal analysis of polychaetes from the Gediz River Delta (Izmir Bay, Aegean Sea). Acta Adriatica, 43(2): 29-42.

Ergen, Z., M.E. Çinar, E. Dağlı and G. Kurt. - 2002b. Lessepsian polychaete species from the Turkish coasts. In: B. Öztürk and N. Başusta (eds.), Workshop on Lessepsian Migration, pp. 5055. Gökçeada.

Ergev, M.B., M.E. Çinar, E. Mutlu and Z. Ergen. - 2003. Ecological features of the lessepsian migrant Leonnates persicus (Polychaeta: Nereididae) from the Levant coast of Turkey. J. Mar. Biol. Ass. U.K., 83: 1225-1226.

Gambi, M.C. and A. Giangrande. - 1986. Distribution of soft-bottom polychaetes in two coastal areas of the Tyrrhenian Sea (Italy): structural analysis. Est. Coast. Shelf Sci., 23: 847-862.

Gambi, M.C., A. Giangrande, M. Martinelli and L.A. Chessa. 1995. Polychaetes of a Posidonia oceanica bed off Sardinia (Italy): spatio-temporal distribution and feeding guild analysis. Sci.Mar., 59: 129-141.

Geldiay, R. and Z. Ergen. - 1972. Deniz Biyolojisi Ara?tırma Laboratuvarı Önündeki Bentik Poliket Faunası Üzerinde Ön Müşahedeler. Ege Üniv. Fen Fak. Ilmi Rap., 1-10.

Geldiay, R. and A. Kocataş. - 1972. Izmir Körfezi'nin benthosu üzerine preliminer bir araştırma. Ege Univ. Fen Fak. Monog. Ser., 12:1-34.

Geldiay, R., Z. Ergen and A. Kocatas. - 1979. Some effects of pollution on the benthic communities of the soft subtrate in the Gulf of Izmir (Turkey). Rapp. Comm. int. Mer. Médit., 25/26, 4: $193-194$

Knox, G.A. - 1977. The role of polychaetes in benthic soft-bottom communities. In: D. J. Reish and K. Fauchald (eds.), Essays on polychaetous annelids in memory of Dr. Olga Hartman, pp: 547-604. Allan Hancock Foundation, University of Southern California, Los Angeles.

Koçak, F., Z. Ergen and M.E. Çinar. - 1999. Fouling organisms and their developments in a polluted and an unpolluted marina in the Aegean Sea (Turkey). Ophelia, 50:1-20.

Kocatas, A. - 1978. Izmir Körfezi Kayalık Sahillerinin Bentik Formları Üzerinde Kalitatif ve Kantitatif Araştırmalar. Ege Üniv. Fen Fak. Monog. Ser., 12: 1-93.

Kocatas, A. - 1980. Evolution cyclique du benthos dans les zones de pollution du golfe d'Izmir (Turquie). Ves Journées Étud. Pollutions, C.I.E.S.M., Cagliari: 643-648.

Kocatas, A., Z. Ergen and T. Katağan. - 1987. Changes in the benthic communities due to various pollutants in Izmir Bay (Turkey). FAO Fish. Rap. (352) Suppl.: 112-122.

Kocatas, A., Z. Ergen, T. Katağan, T. Koray, B. Büyükişik, S. Mater, I. Özel, O. Uçal and M. Önen. - 1986. Etude comparative des particularités physico-chimiques et biologiques dans deux baies polluée et nonpolluée du Golfe d'Izmir. Rapp. Comm. Int. Mer. Médit., 30, 2.

Kontas, A., F. Kucuksezgin, O. Altay and E. Uluturhan. - 2004. Monitoring of eutrophication and nutrient limitation in Izmir Bay (Turkey) before and after wastewater treatment plant. Environmental International, 29: 1057-1062.

Kucuksezgin, F. - 1996. Multivariate analysis of water quality parameters in Izmir Bay, Eastern Aegean. Toxicol. Environ. Chem., 55: 135-144.

Mackie, A.S.Y., C. Parmiter and L.K.Y. Tong. - 1997. Distribution and diversity of polychaeta in the southern Irish Sea. Bull. Mar. Sci., 60: 467-481.

Müezzinoglu, A., D. Sponza, I. Köken, N. Alparslan, A. Akyarlı, and N. Oztüre, N. - 2000. Hydrogen sulfide and odour control in Izmir Bay. Water, Air Soil Pollut., 123: 245-257.

Oug, E. - 2000. Soft-bottom macrofauna in the high-latitude ecosystem of Balsfjord, northern Norway: Species composition, community structure and temporal variability. Sarsia, 85: 1-13.

Pearson, T.H. and R. Rosenberg. - 1978. Macrobenthic succession in relation to organic enrichment and pollution of the marine environment. Oceanogr. Mar. Biol. Ann. Rev., 16: 229-311.

Reish, D.J. - 1955. The realtion of polychaetous annelids to harbor pollution. Publ. Healt. Rep., 70: 1168-1174.

San Martín, G., J. Parapar, F.J. García and M.S. Redondo. - 2000. Quantitative analysis of soft bottoms infaunal macrobenthic polychaetes from South Shetland Islands (Antarctica). Bull. Mar. Sci., 67: 83-102.

Sardá, R., D. Martin, S. Pinedo, A. Dueso and M.J. Cardell. - 1995. Seasonal dynamics of shallow soft-bottom communities in western Mediterranean. In: A. Eleftheriou, A.D. Ansell and C.J. Smith (eds.), The biology and ecology on shallow coastal waters, pp. 191-198. Olsen and Olsen, Fredensborg.

Sardá, R., S. Pinedo and D. Martin. - 1999. Seasonal dynamics of macroinfaunal key species inhabiting shallow soft-bottoms in the Bay of Blanes (NW Mediterranean). Acta Oecologica, 20: 315-326.

Sayin, E. - 2003. Physical features of the Izmir Bay. Cont. Shelf Res., 23: 957-970

Tom, M. and B. Galil. - 1991. The macrobenthic associations of Haifa Bay, Mediterranean coast of Israel. P.S.Z.N.I.: Mar. Ecol., 12: 75-86.

UNEP. - 1994. Integrated management study for the area of Izmir. MAP Tech. Rep., 84.

Received July 28, 2004. Accepted May 11, 2005. 